\title{
Effectiveness of Solution-Focused Brief Counseling to Reduce Online Aggression of Student
}

\author{
Claudy Desya Wiretna, Wahyu Nanda Eka Saputra*, Alif Muarifah, Muya Barida \\ Department of Guidance and Counseling, Universitas Ahmad Dahlan, Indonesia
}

Received January 30, 2020 ; Revised February 17, 2020; Accepted February 24, 2020

Copyright $\mathrm{C} 2020$ by authors, all rights reserved. Authors agree that this article remains permanently open access under the terms of the Creative Commons Attribution License 4.0 International License

\begin{abstract}
The problem of violence committed by adolescents is increasingly complex, one of which is the aggressive behavior of students. In fact, as the 4.0 industrial revolution emerged, the aggressive behavior of students grew, one of which was online aggression. One way counselors can do is to apply solution-focused brief counseling (SFBC) to reduce student online aggression behavior. This study aims to identify the effectiveness of SFBC to reduce student online aggression behavior. This study aims to identify the effectiveness of SFBC to reduce student aggression online behavior. The study design uses quasi-experimental with type nonequivalent control group design. The subjects of this study were students of vocational high school Muhammadiyah 1 Yogyakarta, which had very high online aggression behavior. The data collection tool used to measure online aggression behavior is the scale of online aggression behavior. The data analysis technique used in this study was the independent t-test. The results of this study indicate that online aggression behavior can decrease significantly after being given an SFBC intervention. Students are able to develop a solution that can minimize the desire of students to behave in online aggression.
\end{abstract}

Keywords Online Aggression, Violence, SolutionFocused Brief Counseling

\section{Introduction}

The rapid development of technology will facilitate all activities within the community. One of the works produced from the sophistication of this communication and information technology is social media. In general, social media is one of the media that can be referred to as online media where users can access through Internetbased applications that can be used to create content into the form of wikis, forums, social networks, and virtual world spaces that are supported by increasingly sophisticated multimedia technology. In addition, the use of online media is used by the community as a source of information and communication tools with friends and relatives. The Internet has become a major mass media that provides news, entertainment and media interaction for the public.

Internet media or online media offer content that includes variations between audio, visual, photo and text where this facility is relatively favored by teenagers [1]. The ability of the Internet offers a variety of benefits, including instant access to extraordinary amounts of information, as well as providing communication and entertainment facilities that can be reached with easier access, nor is it denied that the Internet will have a negative impact. Content on online forums and blogs, social media and other online media often and intentionally act offensively with racist, sexist, and homophobic language used to push the limits of politeness and to get attention [2].

The Indonesian Internet Service Providers Association (APJII) states that Internet users in Indonesia are 143.26 million from a total of 262 million people. Of 143.26 million Internet users in Indonesia, $49.52 \%$ of them are young people. This was revealed by the statement of the Secretary-General of APJII that Internet users in Indonesia are based on age, that is, $13-18$ years of age at $16.68 \%$, ages $19-34$ years $49.52 \%$, ages $35-54$ years $29.55 \%$, ages above 54 years $4.24 \%$. The fact that shows that the use of social media is quite high among adolescents as mentioned, it is undeniable that adolescents will be vulnerable to negative impacts from social media. Adolescents will be influenced by the environment in which they live, family, school and peers who are due to the lack of emotional stability that adolescents have to be difficult to control [3]. Teenagers are one of the individuals who is easily provoked emotions to take action aggressiveness, where this shows increasing symptoms in terms of quantity and quality [4].

Several studies have proven that aggressiveness is a classic problem that has not been alleviated today. 
Research on junior-high-school students in the Special Region of Yogyakarta shows that $1 \%$ of students are at a very high level of aggressiveness; $13 \%$ of students are in the high category; $37 \%$ are in the middle category; $43 \%$ are in a low category; $6 \%$ are in the very low category [5]. At the vocational high school level in Yogyakarta, aggression behavior was also found as much as 5\% in the very high category; $26 \%$ in the high category; $40 \%$ in the middle category; $21 \%$ in the low category; and $8 \%$ in the extremely low category [6]. Furthermore, female vocational students have the same tendency toward aggressive behavior as men within the city of Yogyakarta [7].

However, adolescent aggression behavior not only occurs in the real world but also in cyberspace or carried out online by overflowing his aggressive behavior through social media such as Facebook, Instagram, Twitter, and others. The forms of aggression behavior carried out in cyberspace can be categorized as online aggression behavior. Online aggression is cyber-bullying behavior that involves the use of Information and Communication Technology (ICT) to support intentional, repetitive, and unfriendly behavior by a person or group that aims to harm others [8].

The term online aggression is generally used by researchers with different terms such as electronic harassment, cyber aggression, cyber bullying, and others by not distinguishing the terms used [9]. Actions of aggression online can be done in two ways, namely directly or indirectly. The direct form of online aggression is by sending abusive e-mail or SMS while the indirect form of online aggression is by uploading negative content or by spreading gossip [10]. Some research that has discussed cyber bullying, which is also included as online aggression states that not all aggression is bullying, but bullying is aggression [11].

This high online aggression behavior is also found in the schools to be conducted research. In accordance of the results of a preliminary study that has been conducted on students of class XI vocational high school Muhammadiyah 1 Yogyakarta, it is found that from 155 students, there are 16 students $(10.32 \%)$ who have a high category, then 82 students $(52.90 \%)$ with the medium category, and 57 students (36.77\%) with low category. The data was obtained from the spread of the online aggression scale using an instrument developed by Leonardus Edwin [12]. From the preliminary study, it can be concluded that there are still students who have high levels of online aggression behavior with a percentage of $10.32 \%$.

Online aggression carried out by students at the study site is caused by certain factors. One contributing factor is the emergence of a sense of security for the offender when hurting others because the activity is not carried out personally but through online media. Perpetrators are not worried that they will be responded directly physically by the victim so that this can trigger the courage of the perpetrators to conduct online behavior through smartphone media.

The impact arising from online aggression behavior will certainly be very bad, especially for adolescents. Adolescents who have unstable emotions will very easily vent their emotions on social media without thinking about the future impact [13]. Some research also found several factors of online aggression are aggressive messages using dirty words, hate speech, website development that triggers hostility, and the act of commenting on embarrassing photos or videos. From this, it sometimes becomes an unconscious action. If it is left alone, there will be a negative impact on the perpetrators of online aggression and victims [14].

Online behaviors that tend to be dangerous and disruptive such as cyber bullying, online harassment, and electronic aggression are very likely to have various negative impacts [15]. The rapid use of technology by teenagers invites many online interactions where this interaction allows aggressive behavior [16]. This behavior is very influential in suicidal ideation in the perpetrators and the victims who can indirectly be caused by feelings of helplessness, social or academic struggles, and triggered by thoughts that are burdened with problems of adolescent life [17]. Internet harassment is also closely related to depression syndrome in both perpetrators and victims. This is because it is easy to perceive the situation as dangerous [14].

Therefore, there is a need for effective intervention and prevention programs to reduce online aggression behavior. One of the services that can be provided to students to reduce online aggression behavior is to use a Concise Focused Counseling service commonly called solutionfocus brief counseling (SFBC). This counseling model has an effort to focus more on solutions rather than problems, so it aims to accelerate the counselee in finding solutions to the counseling process [18]. This concise counseling approach focuses on solutions that believe that with sustainable change will make students able to change attitudes toward more positive and solutive thinking.

SFBC as a model that has the potential to effectively and efficiently helps counselees find solutions for their problems. SFBC views that humans are individuals who have the competence to develop possible solutions when they have a problem when they are unaware and can be solutive. The SFBC approach also believes that every individual has a solution for his problem, but sometimes they forget about their competence because they are too focused on the problem and only dwell on the problem [18].

Some research has also proven that SFBC can help students get out of the problem of online aggression behavior. SFBC applied in the group settings can be used to help students reduce cyber bullying [19]. Thus, an important point that is this research aims to find out the impact of SFBC on reducing the level of online aggression students have. 


\section{Literatur Review}

Online aggression is a term commonly used to refer to various hostile behaviors carried out with the help of technology or communication media, including the terms electronic bullying, electronic harassment, cyber bullying, the Internet bullying, Internet harassment, cyber bullying, and online harassment by not distinguishing the terms used [10], [13]. Online aggression is cyber bullying behavior aimed at hurting others and there is no personally process, the behavior of sending abusive text messages or entering other people's online accounts without the owner's permission [20]. Several different uses of the term online aggression but do not eliminate the essence of the true meaning, found that online aggression has four aspects, including (a) hostility; (b) communicator; (c) insults; and (d) exclusion [21].

The term cyber bullying itself is following the criteria of online aggression [22]. From various studies that discuss cyber bullying, including online aggression because of the reason that not all aggression is bullying, but bullying is aggression [11]. Besides, referring to the traditional definition of aggression, cyber aggression can be defined as behavior aimed at harming others through computers, cell phones, and other electronic devices and is considered as aversive by victims [23]. Cyber-aggression is a cyber bullying behavior that does not occur personally but by sending abusive text messages or entering other people's online accounts without permission [20].

Online aggression is often referred to as cyber bullying behavior that involves the use of Information and Communication Technology to support intentional, repetitive, and unfriendly behavior by a person or group that is intended to hurt others [22]. This behavior occurs in an individual when they experience conflicts with their peers who resulted in tension [24]. The negative impact of someone who experiences cyber bullying is most likely to experience depression, psychosomatic problems (headaches, recurrent abdominal pain and difficulty sleeping), emotional problems, as well as performing guilty behavior such as drugs, stealing, indiscipline at school and also assault [25].

The problem of student online aggression can be reduced by using SFBC. This counseling approach is a constructivism counseling that focuses on solutions. This counseling model has an effort to focus more on solutions rather than problems, so it aims to accelerate the counselee in finding solutions to the counseling process [18]. The basic assumption of SFBC is to view humans as having the ability to overcome life's challenges, but often people lose direction or awareness of their competencies [26].

SFBC is a goal-oriented counseling approach that focuses on the present and future [27], [28]. This approach is different from traditional approaches that focus on the past and problems. SFBC offers a concise counseling model and brings counselees immediately to find solutions that are by the objectives set. This counseling approach was originally developed by Steve de Shazer and Insoo Kim Berg at the Center for Short Family Therapy in Milwaukee in the early 1980s.

SFBC offers several types of objectives, including changing the appearance of the situation or frame of reference for the problem, changing the implementation of the problematic situation, and exploring the strengths and resources of the counselee rather than discussing their weaknesses [29]. In this study, SFBC is carried out for five meetings, namely (1) building counseling relationships; (2) identify the problem to be solved; (3) building counseling goals; (4) design and implement solutions; and (5) evaluation, termination, and follow-up.

SFBC process has different characteristics from other counseling. There are at least four characteristics of an SFBC procedure, namely (1) find what counselees want rather than trace what they don't want; (2) discover what the counselee has done and lead to success, then encourage them to continue in that direction; (3) if what the counselee does is unsuccessful, encourage them to try to do something different; and (4) briefly conduct each counseling session as if each session was the end of the counseling process [30].

\section{Method}

\subsection{Research Design}

Research on the effectiveness of SFBC to reduce aggressive behavior uses a quasi-experimental type of nonequivalent control group design. The subjects of this study were divided into two groups, namely the experimental group (research subjects were given intervention SFBC) and the control group (research subjects were given conventional counseling interventions). Unlike the true experimental design characteristics, in this study, the research subjects were not randomly divided.

\subsection{Data Collection}

Tabel 1. Online Aggression Scale Indicator

\begin{tabular}{|l|l|}
\hline \multirow{4}{*}{ Aspect } & Indicator \\
\hline \multirow{4}{*}{ Preacher } & Send text with rough sentences \\
\cline { 2 - 3 } Insults & $\begin{array}{l}\text { Commenting on other people's ugliness on social } \\
\text { media }\end{array}$ \\
\cline { 2 - 2 } & $\begin{array}{l}\text { Keep an eye on other people's social media accounts } \\
\text { information with bad intentions }\end{array}$ \\
\hline \multirow{5}{*}{ Exclusion } & $\begin{array}{l}\text { Uploading indecent images on social media } \\
\text { embarrassing others }\end{array}$ \\
\cline { 2 - 2 } & $\begin{array}{l}\text { Block communication access from social media } \\
\text { accounts }\end{array}$ \\
\cline { 2 - 2 } & Delete the list of friends on social media \\
\hline
\end{tabular}


The instrument used in this study is the online aggression scale (OAS). The instrument used in this study consisted of 23 statements, which had been declared valid with coefficients of 0.317 to 0.792 . Cronbach's alpha coefficient value in this study is 0.856 . It can be concluded that it is included in the high-reliability category. Data collection uses instruments based on four aspects online, namely (1) hostility; (2) preacher; (3) insults; and (4) exclusion [31].

\subsection{Subject of Study}

The subjects of this study were students of the vocational high school Muhammadiyah 1 Yogyakarta which had a high level of online aggression category totaling twelve students. The research subjects were divided into two groups not randomly. Six students became the experimental group that was given an SFBC intervention, and six students became the control group that was given a conventional counseling intervention.

Research subjects involved in this study through the process of measurement in advance by using an instrument in the form of online aggression scale and have been identified as students who have high levels of online aggression behavior and have relatively the same characteristics. This was done so that the study subjects were divided into two groups randomly, having relatively the same characteristics, which included the level of online aggression, family background, peers attachment, and age. The characteristics of the two groups that are relatively the same are one of the supporters of the high level of internal validity in this experimental study.

\subsection{Research Stages}

The stages in this research are as follows: First, plan research activities involving the research team; Second, developing research instruments; Third, develop intervention guidelines, both for the experimental and control groups; Fourth, carry out the treatment process; and Fifth, conducting data analysis before and after treatment.

\subsection{Data Analysis Technique}

The data analysis technique used in this study used the Mann-Whitney U Test. This data analysis technique is a non-parametric test used to determine the difference in the median of two groups, namely in this study involving the experimental and control groups. The results of this data analysis will be obtained by comparing data on the level of online aggression in the group of students who are given the intervention of SFBC and the usual intervention given by school counselors.

\section{Results}

The results of the study concluded that there were significant differences in the level of online aggression behavior in the group of students who received the SFBC intervention of the group of students who received the usual counseling intervention given by school counselors. The following table presents the results of the pretest and posttest results from the control and experimental groups.

Table 2. Comparisons of Pretest-Posttest Experiment Groups

\begin{tabular}{|c|c|c|}
\hline \multicolumn{3}{|c|}{ Eksperimental group } \\
\hline No & Subject & Online aggression score \\
\hline 1 & RP & 38 \\
\hline 2 & AA & 51 \\
\hline 3 & DF & 46 \\
\hline 4 & AD & 54 \\
\hline 5 & FW & 42 \\
\hline 6 & HJ & 56 \\
\hline
\end{tabular}

Table 3. Comparisons of Pretest-Posttest Control Group

\begin{tabular}{|c|c|c|}
\hline \multicolumn{2}{|c|}{ Control group } \\
\hline No & Subject & Online aggression score \\
\hline 1 & AR & 55 \\
\hline 2 & FR & 52 \\
\hline 3 & RS & 55 \\
\hline 4 & RF & 55 \\
\hline 5 & RC & 58 \\
\hline 6 & DF & 56 \\
\hline
\end{tabular}

The results of data analysis using the Mann-Whitney U test are as follows.

Table 4. Ranks

\begin{tabular}{|c|c|c|c|c|}
\hline & Strategy & N & Mean Rank & Sum of Ranks \\
\hline \multirow{3}{*}{ OnlAggre } & Counseling & 6 & 8,58 & 51,50 \\
\cline { 2 - 5 } & Sfbc & 6 & 4,42 & 26,50 \\
\cline { 2 - 5 } & Total & 12 & & \\
\hline
\end{tabular}

Table 4 shows that counseling that is commonly done by school counselors gives higher average online aggression ratings for students than students who are given SFBC interventions. This means that the online aggression level of students is higher after being given counseling interventions that are usually done by school counselors than students who are given SFBC interventions. This difference can be said to be significant if in the MannWhitney test, the Asymp. Sig (2-tailed) value is smaller than the alpha level of 0.05 .

In table 5, the Asymp. Sig (2-tailed) value produces a value of 0.043 , which is smaller than alpha 0.05 , so it can be concluded that the average of the two groups is indeed significantly different. That is, SFBC becomes a more effective intervention model for reducing the level of online aggression of students than counseling that is commonly done by school counselors. 
Table 5. Test Statistics

\begin{tabular}{|c|c|}
\hline & OnlAggre \\
\hline Mann-Whitney U & 5,500 \\
\hline Wilcoxon W & 26,500 \\
\hline Z & $-2,019$ \\
\hline Asymp. Sig. (2-tailed) &, 043 \\
\hline Exact Sig. [2*(1-tailed Sig.)] &, $041 \mathrm{~b}$ \\
\hline
\end{tabular}

\section{Discussion}

The results of this study conclude that SFBC is effective and can be used as an alternative aid to reduce online aggression behavior. The results of the study are proven by the data of the decrease in the level of online aggression behavior between before and after given SFBC intervention as many as five meetings, namely (1) building a counseling relationship; (2) identify the problem to be solved; (3) building counseling goals; (4) design and implement solutions; and (5) evaluation, termination, and follow-up. SFBC is one of the interventions that can be used by Guidance and Counseling teachers to reduce students' online aggression behavior.

The SFBC intervention was carried out for five meetings with a duration of approximately 35 minutes per meeting. At the first meeting, building a counseling relationship was carried out using the pretherapy change technique. At the second meeting, identify the problem to be solved using the scaling question technique. At the third meeting, building counseling goals used the miracle question technique. At the fourth meeting, design, and implement solutions using the exception question's technique. In the fifth meeting, evaluation, termination, and follow-up use the scaling question and terminating technique. The five meetings in the SFBC intervention went well, and the research subjects followed the SFBC intervention process correctly.

The concept of SFBC believes that everyone has his solution to the problems in the individual, but sometimes they forget the potential they have because they always look at the problem [18]. This is following the circumstances of individuals who have high online aggression behavior, which considers that the behavior is something natural. Even this behavior is carried out in a conscious state and has an impact on itself and its relationship with the surrounding environment [32]-[34]. However, online aggressors do not try to find solutions to these problems. This SFBC is given to students because this service concept believes that a continuous change will make students able to reduce the level of online aggression so that students can develop behaviors in a more positive direction [18].

Previous research also shows that SFBC can effectively reduce cyber bullying behavior [19]. However, this research takes the object of cyber bullying while in this, the study takes the object of online aggression where the scope is wider because cyber bullying is a small part of online aggression. Some research that has discussed cyber bullying, which is also included as online aggression states that not all aggression is bullying, but bullying is aggression [11].

SFBC is also effective in increasing learning responsibilities [35]. However, the research emphasizes the responsibility of learning, which is a matter of learning and seeks to be improved by SFBC. Whereas in this study the problem is focused on online aggression behavior, which is a social problem and seeks to be reduced with SFBC. Besides, in this study, SFBC was implemented in individual settings, while in these study group settings.

Other studies have concluded that effective SFBC is used to develop students' abilities in controlling compulsive Internet use [36]. However, the results obtained indicate that his research in providing concise counseling services focused on effective solutions used to control compulsive Internet use only on 3 out of four students who were given treatment while in this study concise counseling services focused on solutions capable of reducing online aggression behavior in all students who six students were treated.

Other studies have concluded that creative solutionfocused counseling models (CSFCM) are categorized as feasible to be applied in enhancing self-regulated learning [37]. The SFBC model that is integrated with creative arts or can be called CSFCM is a type of research and development. However, research and development procedures have not identified empirically about the effectiveness of the product. Whereas in this study, testing the effectiveness of SFBC to reduce online aggression behavior. So we get empirical data about the level of difference in online aggression behavior between before and after SFBC intervention is given. The problem identified in the study is self-regulated learning, but the problem identified in this study is online aggression behavior.

Solution-focused brief counseling therapy (SFBT) group counseling can also be used effectively to reduce the truant behavior of students at SMPN 33 Surabaya [38]. However, this study uses a single-subject design research method $A B$ with quantitative visual data analysis by collecting data using observation. In contrast to this study, which uses a quasi-experimental design experimental research with a nonequivalent control group design model. The study also focused more on truant behavior problems, while in this study, the focus was on online aggression behavior problems.

Research on the effectiveness of SFBC is not only found in Indonesia but also abroad. In Korea, the behavior of aggression carried out by adolescents as well decreased significantly after being given a counseling program that focused on solutions [39]. However, research conducted in Korea intervenes in two problems at once, namely general aggression behavior and social adjustment, so there is a concern that there will be bias in the results of research. In 
contrast to this study, the problem raised is specific to online aggression behavior, which is a currently hot problem.

Another research abroad, namely in Texas in the United States also concluded that training using drama, empathy training, and brief therapy that focuses on solutions becomes an integral part that can reduce cyber-bullying effectively [40]. However, in that study, SFBC was not used in its entirety in reducing cyber-bullying. SFBC is one part of the intervention program provided by the counselor in reducing cyber-bullying. Thus, the decrease in cyberbullying is not known due to which intervention, whether drama, empathy training, or SFBC.

Previous studies have also carried out several counseling interventions to reduce online aggression, but have not been able to succeed significantly. An example is the use of SFBC to reduce cyber-bullying [41]. In this study, SFBC can be used to reduce cyber-bullying effectively, but it needs to be combined with dramatic empathy. Group work has also been used by counselors as a strategy to reduce aggressive behavior, however, the study recommends that counselors use counseling to reduce specific behaviors such as aggressive behavior and cyber-bullying [42]. Another example is the use of group counseling with managing emotion techniques that can be used to prevent student aggressiveness [43]. However, this research is only limited to preventing the emergence of aggressive behavior and has not overcome the problem that has emerged in the form of behavior, namely online aggression. This is also the reason for designing and testing SFBC to reduce student's online aggression. The peace counseling approach can also be used to help counselees reduce aggressive behavior [44]. However, unlike SFBC, which has a relatively short process, the peace counseling approach requires a relatively long time for the counseling process.

The reduced level of online aggression in students is possible not only influenced by SFBC intervention, but other factors also contribute to the decline in online aggression. The contributing factor to the decline in online aggression in peer relations. Peers are proven to be one of the causes of high or low levels of online aggression in students [45], [46]. Another factor that has been shown to support decreased online aggression is family factors [47]. The emergence of warmth in the family is proven to affect the low online aggression, so, it is recommended for parents to pay attention to their children when interacting with the Internet. Several factors that threaten the internal validity of SFBC interventions carried out have been controlled by eliminating research subjects that do not have the same relative characteristics, which include the level of online aggression, family background, peer attachment, and age.

Research that identifies differences in online aggression behavior using SFBC has several limitations. The limitation of this research is the use of research instruments that are only limited to the scale of online aggression so that they are unable to describe in detail the forms of online aggression that arise in students. Another limitation of this study is the use of quasi-experimental design research with the nonequivalent control group design model. Thus, assignments in the control and experimental groups are not carried out randomly.

\section{Conclusions}

Online aggression is a new problem developing at this time. This problem has a negative impact on the perpetrators and victims if not handled properly and quickly. In this study, a trial was conducted to find out one approach to counseling, namely SFBC to reduce online aggression in students. The results of the study concluded that SFBC is effective for counselors to use to reduce online aggression in students. The results of this study recommend that school counselors apply SFBC to help students reduce online aggression behavior.

\section{Acknowledgements}

Thank you to the guidance and counseling study program, Ahmad Dahlan University, for providing support to this research activity. Besides that, thanks are also given to the leadership in the guidance and counseling study program and the supervisor who has guided the process of this research.

\section{REFERENCES}

[1] G. R. Adiarsi, Y. Stellarosa, and M. W. Silaban, "Literasi media internet di kalangan mahasiswa," Humaniora, vol. 6, no. 4, pp. 470-482, 2015.

[2] M. S. Bernstein, A. Monroy-Hernández, D. Harry, P. André, K. Panovich, and G. G. Vargas, "4chan and/b: An Analysis of Anonymity and Ephemerality in a Large Online Community.," in ICWSM, 2011, pp. 50-57.

[3] S. Burnett, G. Bird, J. Moll, C. Frith, and S.-J. Blakemore, "Development during adolescence of the neural processing of social emotion," J. Cogn. Neurosci., vol. 21, no. 9, pp. 1736-1750, 2009.

[4] D. F. Connor, Aggression and antisocial behavior in children and adolescents: Research and treatment. Guilford Press, 2012.

[5] S. Alhadi, P. Purwadi, S. Muyana, W. N. E. Saputra, and A. Supriyanto, "Agresivitas Siswa SMP di Yogyakarta," J. Fokus Konseling, vol. 4, no. 1, pp. 93-99, 2018.

[6] W. N. E. Saputra and I. B. Handaka, "Perilaku Agresi Pada Siswa SMK di Yogyakarta,” J. Fokus Konseling, vol. 4, no. 1, pp. 1-8, 2018.

[7] W. N. E. Saputra, N. Hanifah, and D. N. Widagdo, 
"Perbedaan Tingkat Perilaku Agresi Berdasarkan Jenis Kelamin pada Siswa Sekolah Menengah Kejuruan Kota Yogyakarta,” J. Kaji. Bimbing. Dan Konseling, vol. 2, no. 4, pp. 142-147, 2017.

[8] B. Belsey, "Cyberbullying: An emerging threat to the 'always on' generation,” Recuperado El, vol. 5, 2005.

[9] J. Pyżalski, "From cyberbullying to electronic aggression: Typology of the phenomenon," Emot. Behav. Difficulties, vol. 17, no. 3-4, pp. 305-317, 2012.

[10] J. Pyzalski, "Electronic aggression among adolescents: An old house with a new facade (or even a number of houses)," in Youth culture and net culture: Online social practices, IGI Global, 2011, pp. 278-295.

[11] K. S. Berger, "Update on bullying at school: Science forgotten?” Dev. Rev., vol. 27, no. 1, pp. 90-126, 2007.

[12] L. E. Gandawijaya, "Hubungan antara kontrol diri dan agresi elektronik pada pengguna media sosial di masa transisi menuju dewasa," PhD Thesis, Sanata Dharma University, 2017.

[13] C. David-Ferdon and M. F. Hertz, "Electronic Media and Youth Violence: A CDC Issue Brief for Researchers.," Cent. Dis. Control Prev., 2009.

[14] M. L. Ybarra and K. J. Mitchell, "Online aggressor/targets, aggressors, and targets: A comparison of associated youth characteristics," J. Child Psychol. Psychiatry, vol. 45, no. 7, pp. 1308-1316, 2004.

[15] I. Kellerman, G. Margolin, L. A. Borofsky, B. R. Baucom, and E. Iturralde, "Electronic aggression among emerging adults: Motivations and contextual factors," Emerg. Adulthood, vol. 1, no. 4, pp. 293-304, 2013.

[16] M. F. Wright and Y. Li, "Normative beliefs about aggression and cyber aggression among young adults: A longitudinal investigation," Aggress. Behav., vol. 39, no. 3, pp. 161-170, 2013.

[17] S. Hinduja and J. W. Patchin, "Bullying, cyberbullying, and suicide,” Arch. Suicide Res., vol. 14, no. 3, pp. 206-221, 2010.

[18] G. Corey, Theory and practice of counseling and psychotherapy. Nelson Education, 2015.

[19] A. Aminudin and K. Karyanti, "Layanan konseling kelompok solution focused brief therapy (SFBT) untuk mengurangi perilaku cyber bullying pada peserta didik kelas VIII-7 di SMPN-3 Palangka Raya," SULUH J. Bimbing. dan Konseling, vol. 3, no. 1, pp. 12-18, 2017.

[20] D. W. Grigg, "Cyber-aggression: Definition and concept of cyberbullying," J. Psychol. Couns. Sch., vol. 20, no. 2, pp. 143-156, 2010.

[21] D. C. Bennett, E. L. Guran, M. C. Ramos, and G. Margolin, “College students' electronic victimization in friendships and dating relationships: Anticipated distress and associations with risky behaviors," Violence Vict., vol. 26, no. 4, pp. 410-429, 2011.

[22] D. M. Law, J. D. Shapka, J. F. Domene, and M. H. Gagné, "Are cyberbullies really bullies? An investigation of reactive and proactive online aggression," Comput. Hum. Behav., vol. 28, no. 2, pp. 664-672, 2012.
[23] S. Hinduja and J. W. Patchin, "Cyberbullying: An exploratory analysis of factors related to offending and victimization," Deviant Behav., vol. 29, no. 2, pp. 129-156, 2008.

[24] F. S. Rahayu, S. Widjajani, and M. Z. Romas, "Iptek Bagi Masyarakat Siswa Dalam Menyikapi Fenomena Cyberbullying Di Kalangan Remaja,” J. Abdimas, vol. 17, no. 2, pp. 89-96, 2013.

[25] Q. Li, P. K. Smith, and D. Cross, "Research into cyberbullying," Cyberbullying Glob. Play. Res. Int. Perspect., vol. 1, 2012.

[26] J. S. Kim, "Examining the effectiveness of solution-focused brief therapy: A meta-analysis," Res. Soc. Work Pract., vol. 18, no. 2, pp. 107-116, 2008.

[27] E. Connie, L. Metcalf, and L.-S. LPC-S, The art of solution focused therapy. Springer Publishing Company, 2009.

[28] R. S. Sharf, Theories of psychotherapy \& counseling: Concepts and cases. Cengage Learning, 2015.

[29] B. O'Hanlon, W. H. O'Hanlon, and M. Weiner-Davis, In search of solutions: A new direction in psychotherapy. WW Norton \& Company, 2003.

[30] J. L. Walter and J. E. Peller, Becoming solution-focused in brief therapy. Routledge, 2013.

[31] D. C. Bennett, E. L. Guran, M. C. Ramos, and G. Margolin, 'College students' electronic victimization in friendships and dating relationships: Anticipated distress and associations with risky behaviors', Violence and victims, vol. 26, no. 4, pp. 410-429, 2011.

[32] L. Marsh, R. McGee, and S. Williams, "School climate and aggression among New Zealand high school students," N. Z. J. Psychol., vol. 43, no. 1, pp. 28-37, 2014.

[33] S. B. Mehta, D. Cornell, X. Fan, and A. Gregory, "Bullying climate and school engagement in ninth-grade students," J. Sch. Health, vol. 83, no. 1, pp. 45-52, 2013.

[34] D. E. Thomas, K. L. Bierman, C. J. Powers, and C. P. P. R. Group, "The influence of classroom aggression and classroom climate on aggressive-disruptive behavior," Child Dev., vol. 82, no. 3, pp. 751-757, 2011.

[35] F. Mutakin, N. Hidayah, and M. Ramli, "Efektivitas Konseling Ringkas Berfokus Solusi untuk Meningkatkan Tanggung Jawab Belajar Siswa SMP," J. Pendidik. Teori Penelit. Dan Pengemb., vol. 1, no. 11, pp. 2220-2225, 2016.

[36] Y. Nurmalasari, "Konseling Singkat Berfokus Solusi dalam Mengembangkan Kemampuan Mengendalikan Compulsive Internet Use Siswa,” EMPATI-J. Bimbing. Dan Konseling, vol. 3 , no. $2 / \mathrm{Ok}, 2016$.

[37] W. N. E. Saputra, A. Da Costa, and S. Alhadi, "Creative Solution Focused Counseling Models (CSFCM): Strategi Kreatif untuk Mengembangkan Self-regulated Learning Siswa," J. Kaji. Bimbing. Dan Konseling, vol. 3, no. 4, pp. 162-170, 2018

[38] P. Setyowati and T. I. Pratiwi, "Penerapan Konseling Kelompok Pendekatan Solution-Focused Brief Therapy untuk Mengurangi Perilaku Membolos Siswa di SMPN 33 Surabaya,”J. BK UNESA, vol. 9, no. 3, 2019.

[39] S.-K. Shin, "Effects of a solution-focused program on the 
reduction of aggressiveness and the improvement of social readjustment for Korean youth probationers,” J. Soc. Serv. Res., vol. 35, no. 3, pp. 274-284, 2009.

[40] J. Froeschle Hicks, B. Le Clair, and S. Berry, "Using solution-focused dramatic empathy training to eliminate cyber-bullying," J. Creat. Ment. Health, vol. 11, no. 3-4, pp. 378-390, 2016.

[41] J. Froeschle Hicks, B. Le Clair, and S. Berry, "Using Solution-Focused Dramatic Empathy Training to Eliminate Cyber-Bullying," J. Creat. Ment. Heal., vol. 11, no. 3-4, pp. 378-390, 2016.

[42] A. M. Horne, J. L. Stoddard, and C. D. Bell, "Group Approaches to Reducing Aggression and Bullying in School," Gr. Dyn., vol. 11, no. 4, pp. 262-271, 2007.

[43] V. D. Krisnanda, "Effectiveness of Managing Emotion Techniques in Group Counseling to Prevent Aggressiveness of High School Students," Sosio e-Kons, vol. 11, no. 2, pp. 108-114, 2019

[44] W. N. E. Saputra et al., "Peace Counseling Approach (PCA ) to Reduce Negative Aggressive Behavior of Students," vol. 8, no. 2, pp. 631-637, 2020, doi: 10.13189/ujer.2020.080236.

[45] C. D. Pornari and J. Wood, "Peer and cyber aggression in secondary school students: The role of moral disengagement, hostile attribution bias, and outcome expectancies," Aggress. Behav., vol. 36, no. 2, pp. 81-94, 2010.

[46] M. Wright et al., "Peer Attachment and Cyber Aggression Involvement among Chinese, Indian, and Japanese Adolescents," Societies, vol. 5, no. 2, pp. 339-353, 2015.

[47] M. Law, J. D. Shapka, and B. F. Olson, "To control or not to control? Parenting behaviours and adolescent online aggression," Comput. Human Behav., vol. 26, no. 6, pp. 1651-1656, 2010 